\title{
Germination Assessment for Five Species of Acacia in Jibala, Saudi Arabia
}

\section{Gallab Bander Alotaibi1 , Ibrahim Mohamed Aref2}

\author{
${ }^{1}$ Department of Biological Sciences, Faculty of Science and Humanities, Shaqra University, P.O. Box 1040 Al- \\ Dawadmy 11911, Saudi Arabia \\ ${ }^{2}$ Department of Plant Production, King Saud University, Riyadh P. O. Box 2460, Saudi Arabia
}

\begin{abstract}
Most Acacia species have a hard seed coat and therefore have become more resistant to unsuitable environmental conditions. The study aimed to assess the effects of different treatments on seed germination collected from five species of Acacia in Jibala, Al-Dawadmy, a city located in the Riyadh region of Saudi Arabia. The results showed that the highest germination percentage was $90.8 \%$, with scarification treatment, while the lowest germination percentage was $30.9 \%$, utilising a boiling treatment lasting seven minutes. Among the studied species, the seeds of $A$. ehrenbergiana produced the highest percentage of germination and the lowest germination time average among the studied species, while the lowest germination percentage and the highest germination time averages were found in A. nubica. Concluding, this study proved that scarification was the most effective technique for increasing germination rates, compared to other treatments.
\end{abstract}

Keywords: Acacia Species, Scarification, Boiling, Treatment, Socking, Germination

\begin{abstract}
Introduction
The genus Acacia is one of the most important tree components of the flora in Saudi Arabia (Aref et al., 2003). Acacia spp. is widely distributed in arid and semi-arid regions. (Demel, 1996; Wilson and Witkowski, 1998). Acacia is currently attracting great interest due to their drought resistance (Oba et al., 2001) and multiple uses, including fodder, wood and non-wood products (gums, resins and pharmaceuticals) for local communities, provision of shade and live fencing (Noad and Birnie, 1989) and in maintaining soil fertility through nitrogen fixation (Belsky et al., 1989). It is also well known that Acacia species are very important sources of nonwood products in arid and semi-arid environments (Kassa et al., 2010).
\end{abstract}

FAO (2007) estimated worldwide annual deforestation at 13 million ha or $0.7 \%$ of the total forested area. The germination process is considered the most important and crucial factor in a plant life cycle, as it seriously affects the successful execution of afforestation and reforestation programmes (Vibekke et al., 2004; Bu et al., 2008). Numerous techniques have been used to render Acacia and other seeds permeable, including scarification and soaking in tap water, boiling or hot water, acids, organic solvents and alcohols (Bonner et al., 1974; Clemens et al., 1977; Zwaan, 1978; Delwaulle, 1979; Cavanagh, 1980a; ISTA, 1981; Ren and Tao, 2004; Patane and Gresta, 2006; Okunomo and Bosah, 2007;
Kassa et al., 2010). Most Acacia spp. have hard seed coats impervious to water (Demel, 1996; Baskin and Baskin, 1998; Walters et al., 2004). One of the characteristics of the seeds of some desert species, especially those affiliated with the family Fabaceae, such as Acacia tortilis and Acacia gerradii, is a thick testa that does not allow water to enter, so the seed cannot grow unless it is carried away from the native plant and part of it is scraped by rocks and gravel or by exposure to different temperatures and high humidity, all of which can lead to its softening and rendering in water (Alnafia 1425). A. negrii seeds were studied (Demel, 1996) and it has been shown that seed testa can be broken by mechanical scratching, acid treatment, boiling water, and by a dry heating treatment. All previous treatments have improved and increased the germination rate of many species of acacia. In a study conducted by Okunomo and Bosah (2007), several treatments were used to germinate seeds of $A$. senegal in Nigeria. The most important of those treatments were immersion in warm water at $60^{\circ} \mathrm{m}$ and $28^{\circ} \mathrm{m}$ for $5,10,15$, or 20 minutes, plus a control, and cold-water immersion for $12,24,48$, or 72 hours. Finally, the experimenters used diluted sulphuric acid for 5, 15, and 20 minutes, plus a control. The results showed that a 20 -minute seed-acid treatment gave the highest germination percentage, $90 \%$. This compares to other acid treatments yielding germination in three days, while the rate for immersion in cold water for 48 hours is

This article is published under the terms of the Creative Commons Attribution License 4.0

Author(s) retain the copyright of this article. Publication rights with Alkhaer Publications.

Published at: http://www.ijsciences.com/pub/issue/2018-09/

DOI: 10.18483/ijSci.1797; Online ISSN: 2305-3925; Print ISSN: 2410-4477 
higher by comparison. Other cold-water immersion periods yielded a $60 \%$ germination rate after 21 days.

Scarification can be carried out in a number of ways, both manual and mechanical, all designed to remove part of the seed's coat so as to allow access to water straight to the foetus. This is an appropriate treatment of small seed quantities for research purposes (Msanga 1998). Wolf and Kamondo (1993) showed that scarification is an effective means of breaking cumin in seed in a number of trees, including $A$. tortilis and $A$. seyal, and that approach has been used for small quantities of seeds in scientific research. For example, Bockarie et al. (1993) successfully used sandpaper to break cumin seeds in Cassia sieberian, an approach which resulted in high and ideal germination. This study therefore sought to assess the effects of four treatments (acid, boiling, soaking and scarification) on five species of Acacia.

\section{Materials and Methods}

Jibala, the area studied, is located in Al-Dawadmi and is one of the rarest areas populated by acacia species in the Riyadh region. Jibala lies in the north-western portion of the region, around $80 \mathrm{~km}$ from the city of Al-Dawadmy, at coordinates $24^{\circ} 48^{\prime} 11.0^{\prime \prime} \mathrm{N}$ and $43^{\circ} 53^{\prime} 27.2^{\prime \prime} \mathrm{E}$, at an altitude of nearly $924 \mathrm{~m}$ above sea level (Fig.1.).

\section{Environmental Data}

Climate data was collected by Buryadh station, the station nearest the study area. The data was utilised to identify thermal rain factors from 1985 to 2008 (Table 1), using Emberger's equation (Emberger, 1971).

Emberger's equation:

$Q^{2}=$

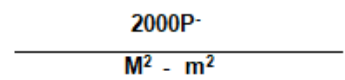

Where

$\left(Q^{2}\right)$ is pluviometric coefficient.

$(\mathrm{P})$ is the mean of rainfall each year $(\mathrm{ml})$.

(M) is the mean of the highest temperatures each month.

(m) is the mean of lowest temperatures each month. The mean of highest $(\mathrm{M})$, lowest $(\mathrm{m})$ temperature and rainfall rate $(\mathrm{P})$ for the whole period were calculated as follows:

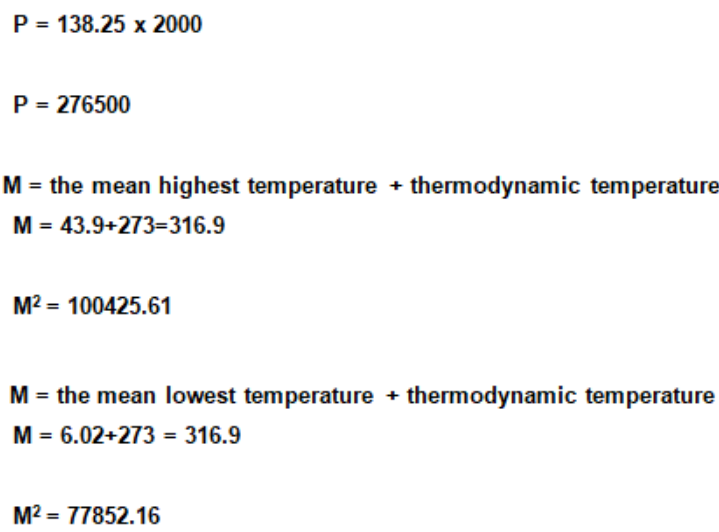

This result was presented by Emberger graph to identify the climate location for the Buryadh station. Climate data from 1985 to 2008 at Buryadh station (Table 1) showed that the highest temperatures ranged between $46.1^{\circ}$ and $42^{\circ}$ during June, July and August each year, while the lowest temperatures ranged between $2.3^{\circ}$ and $10.9^{\circ}$ during December, January and February of each year (Figure 2).

The annual rainfall rate from 1985 to 2008 at Buryadh station ranged between $55 \mathrm{~mm}$ and 248.6 mm each year (Fig.2.). Climate location for Buryadh station was presented by Emberger's factor and it's located in a very dry zone (Saharan), based upon climate data of Buryadh station at 12.25 (Fig.4.).

\section{Seeds collection and experimental Design}

Seeds were collected from the various species by shaking trees and were then stored in plastic tanks to transport to the laboratory. Experimental Design followed methods described by Aref et al. (2011), Four treatments were used: sulphuric acid (98\%) for five periods of $5,10,15,20$ and 25 minutes; boiling at $100 \mathrm{C}^{0}$ for four periods, $1,3,5$ and 7 minutes; soaking for periods of 24, 48 and 72 hours; and scarification: seeds were scarified manually by cutting $1 \mathrm{~mm}$ of the seed coat. A total of 25 seeds were placed on three layers of Whatman filter paper No. 3 in $9 \mathrm{~cm}$ Petri dishes. Four replicates were used for each treatment, plus the control. Filter papers were kept moistened and distilled water was added whenever needed throughout the duration of the experiments. Petri dishes were kept in a Weiss Technik growth chamber) at a constant temperature $\left(30 \pm 1^{\circ} \mathrm{C}\right)$ and $12 / 12 \mathrm{~h}$ light and darkness. Germination was monitored daily and recorded. Seeds were considered germinated when the healthy, white radical had emerged through the integument. 
Determination of germination parameters.

The following germination parameters were determined by:

(1) Germination percentage (GP); the number of germinated seeds as a percentage of the total number of tested seeds is given as:

$\mathrm{GP}=($ germinated seeds/total tested seeds $) \times 100 \%$

(2) Germination mean time, given according to Scott et al. (1984) as:

(GMT days): $=\Sigma$ ti Ni / S

Where ti is the number of days from the beginning of the experiment, $\mathrm{Ni}$ the number of seeds germinated per day and $\mathrm{S}$ is the total number of seeds germinated.

(3) Coefficient of variation of the germination time is calculated by the expression,

$$
C V_{t}=\frac{s_{t}}{\bar{t}} 100
$$

Where st: standard deviation of the germination time and $\overline{\mathrm{t}}$ : mean germination time. An Excel function was used to calculate: $=\operatorname{SQRT}((G 17 /(C 17-1)) / C 19 * 100$. Replications or samples with only one seed germinated do not have the value of this measurement because the divisor of the variance of the germination time is zero.

\section{Results}

Statistical analysis of the influence of seeds treatments on germination rates for five species of acacia showed that in A. ehrenbergiana there was no significant difference between mechanical scarification treatments, acid treatments, boiling 7 minutes and soaking 24 hours, while there was significant difference in germination rates between acid treatments and boiling 3 or 5 minutes $-79 \%$ and $72 \%$, respectively. There was also significant difference in germination rates between acid treatments, $92 \%$ and $97 \%$, and soaking treatments of 48 and 72 hours, which were $73 \%$ and $77 \%$, respectively. The highest germination was in $A$. gerardii var. najednsis by mechanical scarification which was $100 \%$ (Table 2). In A. nubica, the differences between mechanical scarification treatment and other treatments in germination rate were significant. The highest germination rate was $53 \%$ in mechanical scarification treatment, compared to other treatments, while there were not significant differences between boiling treatments. In $A$. raddiana, the highest germination rate was $97 \%$ in mechanical scarification treatment, while other treatments did not result in a significant difference. There was, however, significant difference in $A$. tortilis between boiling treatments 1,5 and 7 minutes, with germination rates of $70 \%, 47 \%$ and $34 \%$, respectively (Table 2).

The highest germination rate in A. Ehrenbergiana was $97 \%$ with acid treatment of 15 minutes, while the lowest germination rate was $72 \%$, produced by a boiling treatment of 5 minutes (Fig.5.). Germination treatments in $A$. gerardii revealed that the highest germination rate was $90 \%$ with mechanical scarification treatment, whereas the lowest germination rate was $6 \%$ generated by soaking for 72 hours (Fig.6.). The germination rate of $A$. raddiana and $A$. tortilis was the highest with mechanical scarification treatment, $97 \%$ and $93 \%$, respectively, while the lowest germination rate in A. raddiana was $18 \%$ by several treatments, including control, boiling 7 minutes and soaking 48 hours, but in A. tortilis the rate was $43 \%$, produced by boiling for 7 minutes (Fig.7 and 8.). The lowest germination rate was $0 \%$ in A. nubica by the control treatment, whereas the highest was $53 \%$ by mechanical scarification (Fig.9.).

Germination rate was influenced by treatments, with mechanical scarification generating the highest coefficient of velocity of germination (CV) and germination percentage. While it was the lowest in mean germination time (MGT) (Table 3). Germination rate was also influenced by species. The coefficient of velocity of germination (CV) was the highest in A. ehrenbergiana while it was the lowest in A. nubica. In contrast, mean germination time (MGT) was the highest in A. nubica, whereas MGT was the lowest in A. ehrenbergiana. Germination percentage was the highest in A. ehrenbergiana and the lowest in A. nubica.

\section{Discussion}

Most plants in arid zones which have hard seed coats have become more resistant to unsuitable environmental conditions (Washitani and Masuda, 1990; Fenner, 1991; Meyer et al., 1991; Silvertown, 1999). In this particular environment, seeds take a long time to grow into seedlings (Morgan, Wang et al., 1998). Breaking seed dormancy is an important factor in producing a large number of seedlings (Lodge and Whalley, 2002), and germination treatment is an effective and important method of breaking seed dormancy.

In this study, germination treatments created high germination rates in most acacia seeds. Scarification treatment was more productive than other treatments because germination was better and faster in all five tested species of acacia. This confirmed that seeds of some desert species, including Acacia tortilis, Acacia gerrardii and Acacia tortilis, needs to be removed from the native plant and part of it scraped to allow water entry inside the seed (Alnafia 1425). Scarification also proved an appropriate treatment of small seed quantities for research purposes (Msanga 1998). Bockarie et al. (1993) used sandpaper to break cumin seeds for Cassia sieberiana and this produced high and ideal germination rates. Acid treatment was 
also effective, but its cost was high and its use was dangerous compared to other treatments, according to Bonner et al. (1974). Boiling treatment produced less germination than acid treatment because acid has the ability to breach the seed coat barrier to enable imbibition and germination to take place (Masamba, C., 1994). Soaking treatment also was more effective than the control, and it enhanced germination rate in many species, including Acacia mearnsii, $A$. melanoxylon, A. nilotica, and A. procera (Matias et al. 1973).

\section{Conclusion}

Germination rates in all acacia seeds were varied between treatments, but all were significantly improved by those treatments. Mean germination time (MGT) was between 3 and 9 days for all acacia species which were studied. A. ehrenbergiana had the highest germination rate and the lowest in mean germination time compared to other species. In contrast, A. nubica had the lowest germination rate and the highest mean germination time. This occurred because nubica seeds have a thick, strong testa, which requires particular treatments to break cumin in seed (Wolf and Kamondo 1993). As a result, acacia seed characteristics have become better at breaking cumin and germinated more quickly

Acknowlegement

The authors extend their appreciation to both King Saud and shaqra Universities in Kingdom of Saudi Arabia for providing funding and facilities for this work.

\section{REFRENCES}

1. Alnafia, A. (2004). Plants Geographical Distribution, Saudi Arabia Desert Plants, Saudi Arabia Plants, Saudi Arabia Climate Environment. Riyadh: p. H. Aldafia: ISBN 9960-46751-1, Edition I 1.

2. Aref IM, El-Juhany LI, Hegazy SS (2003). Comparison of the growth and biomass production of six Acacia species in Riyadh, Saudi Arabia after 4 years of irrigated cultivation. J. Arid Environ., 54: 783-792.

3. Aref, I.M., H.A.E. Hashim, T.A. Shahrani, and A.I Mohamed. 2011. Effects of seed pretreatment and seed source on germination of five Acacia spp. African Journal of Biotechnology 10(71): 15901-15910. doi: 10.5897/AJB11.1763

4. Baskin C, Baskin J (1998). Seeds, Ecology, Biogeography and Evolution of Dormancy and Germination. Academic Press, London.

5. Belsky AJ, Amundson RG Duxbury JM, Riha SJ, Ali AR, Mwonga SM (1989). The effects of trees on their physical, chemical and biological environments in a semiarid savanna in Kenya. J. Appl. Ecol., 26:1005-1024.

6. Bockarie, A.H.; Duryea, M.L.; West, S.H.; White, S.L. (1993). Pretreatment to overcome seed coat dormancy in Cassia sieberiana. Seed Science and Technology. 21: 383398.

7. Bonner FT, McLemore BF, Barnett JP (1974). Pre-sowing treatment of seed to speed germination, pp. 126-35 in 'Seeds of Woody Plants in the United States'. Agric. Handbook No. 450. Forest Service, Washington, D.C.
8. Bu, H., G., Du, X., Chen, X., Xu, K., Liu. and S., Wen, 2008. Communitywide germination strategies in an alpine meadow on the eastern Qinghai-Tibet plateau: Phylogenetic and lifehistory correlates. Plant Ecol. 195:87-98.

9. Cavanagh, A.K., (1980a). A review of some aspects of the germination of acacias. Proc., R. Soc., Vict. 91(1-2), 161-80.

10. Clemens, J., P.G., Jones, and N.H., Gilbert, 1977. Effect of seed treatments on germination in Acacia. Australian J. Bot. 25: 269-76.

11. Delwaulle JC (1979). Forest plantations in dry tropical Africa. Revue Bois et Foret des Tropiques, 187: 117-44.

12. Demel T (1996). Germination ecology of twelve indigenous and eight exotic multipurpose leguminous species from Ethiopia. For. Ecol. Manage. 80: 209-223.

13. Emberger, L. (1971). Considération Complémentaries au sujet des recherches, bioclimatiques et phytogéographiques, écoloqiques in travaur de botanique et décologie, Massonéd: 291-301

14. FAO (Food and Agriculture Organization of the United Nation), 2007. State of the World's forests. Rome.

15. ISTA, (1981). Amendments to International Rules for Seed Testing 1976. Intern. Seed Test. Assoc. (Zurich: Switzerland).

16. Kassa A, Alia R, Tadesse W, Pando V, Bravo F (2010). Seed germination and viability in two African Acacia species growing under different water stress levels. Afr. J. Plant Sci., 4(9): 353-359.

17. Masamba, C., 1994. Presowing seed treatments on four African Acacia species: appropriate technology for use in agroforestry for rural development. Forest Ecology and Management 64, 105-109.

18. Msanga, H.P. 1998. Seed Germination of Indigenous Trees in Tanzania. Northern Forestry Centre, Canadian Forest Service.

19. Noad T, Birnie A, (1989). In: Noad T, Birnie A (Eds.). Trees of Kenya, second ed. Nairobi, p. 169.

20. Oba G, Nordal I, Stenseth NC, Stave J, Bjora CS, Muthondeki JK, Bii WKA (2001). Growth performance of exotic and indigenous tree species in saline soils in Turkana, Kenya J. Arid Environ. 47: 499-511.

21. Okunomo K, Bosah BO (2007). Germination response of Acacia senegal (Linn.) seeds to various presowing trteatments in the nursery. Agric. J. 2(6): 681-684.

22. Patane C Gresta F (2006). Germination of Astragalus hamosus and Medicago orbicularis as affected by seed-coat dormancy breaking techniques. J. Arid Environ. 67: 165-173.

23. RANAL, M.A. \& SANTANA, D.G. 2006. How and why to measure the germination process? Revista Brasileira de Botânica 29:1-11.

24. Ren J, Tao L (2004). Effects of different pre-sowing seed treatments on germination of 10 Calligonum species. For. Ecol. Manage. 195: 291- 300.

25. Scott SJ, Jones RA,Williams WA(1984). Review of data analysis methods for seed germination. Crop Sci., 24: 11921198. Sheridan PM, Karowe DN (2000). Inbreeding, out breeding, and heterosis in the yellow pitcher plant. , Sarracenia flava (Sarraceniaceae) in Virginia. Am. J. Bot. 87: 1628-1633

26. Vibekke V, Heuch I, Vandvik V (2004). Do seed mass and family affect germination and juvenile performance in Knautia arvensis? A study using failure-time methods. Acta. Ecol., 25: 169-178.

27. Walters M, Midgley JJ, Somers MJ (2004). Effects of fire and fire intensity on the germination and establishment of Acacia karoo, Acacia nilotica, Acacia luederitzii and Dichrostachys cinerea in the field. BMC. Ecol., 4: 1-13.

28. Wilson TB, Witkowski TF (1998). Water requirements for germination and early seedling establishment in four African savanna woody plant species. J. Arid Environ. 38: 541-550.

29. Wolf H, Kamondo B (1993) Seed pre-sowing treatment. In: Albrecht J (ed) Tree seed handbook of Kenya. Kenya Forestry Research Institute/ Gesellschaft für Technische Zusammenarbeir, Nairobi, Kenya, pp 55-62. 
Germination Assessment for Five Species of Acacia in Jibala, Saudi Arabia

30. Zwaan JG (1978). The effects of hot-water treatment and stratification on the germination of Blackwood (Acacia

melanoxylon) seed. South Afr. For. J., 105: 2-40.

\begin{tabular}{|c|c|c|c|c|c|}
\hline Year & $\begin{array}{l}\text { The highest } \\
\text { temperature }\end{array}$ & Month & $\begin{array}{l}\text { The lowest } \\
\text { temperature }\end{array}$ & Month & Rainfall rate $(\mathrm{P})$ \\
\hline 1985 & 42.4 & 8 & 6.5 & 2 & 140.9 \\
\hline 1986 & 42.8 & 8 & 6.1 & 1 & 161.3 \\
\hline 1987 & 44.2 & 7 & 5.44 & 1 & 118.5 \\
\hline 1988 & 42.7 & 7 & 7 & 1 & 86.2 \\
\hline 1989 & 43 & 7 & 10.9 & 1 & 96.2 \\
\hline 1990 & 42.5 & 7 & 5.5 & 1 & 55 \\
\hline 1991 & 42 & 6 & 7 & 1 & 163 \\
\hline 1992 & 42 & 8 & 2.3 & 1 & 194.9 \\
\hline 1993 & 42.9 & 8 & 5.6 & 1 & 199.2 \\
\hline 1994 & 42.4 & 8 & 6.6 & 12 & 129.6 \\
\hline 1995 & 43.6 & 8 & 7.39 & 1 & 248.6 \\
\hline 1996 & 44.5 & 7 & 8.58 & 1 & 127.3 \\
\hline 1997 & 43.4 & 6 & 5.3 & 2 & 240.5 \\
\hline 1998 & 46.1 & 8 & 6 & 1 & 108.6 \\
\hline 1999 & 44.9 & 8 & 6.5 & 12 & 99 \\
\hline 2000 & 45.8 & 8 & 5.8 & 1 & 156.1 \\
\hline 2001 & 46 & 8 & 4.5 & 1 & 152.1 \\
\hline 2002 & 45 & 7 & 6.2 & 1 & 155.6 \\
\hline 2003 & 45.3 & 8 & 5.2 & 1 & 78.5 \\
\hline 2004 & 44.5 & 7 & 5.68 & 1 & 159.8 \\
\hline 2005 & 43.9 & 8 & 5.79 & 1 & 202.8 \\
\hline 2006 & 44.5 & 8 & 4.8 & 12 & 79.6 \\
\hline 2007 & 44 & 8 & 4.8 & 1 & 64.3 \\
\hline 2008 & 44.8 & 8 & 4.9 & 1 & 100.3 \\
\hline \multirow[t]{2}{*}{ Average } & $\begin{array}{c}\text { The mean of } \\
\text { highest } \\
\text { temperature }\end{array}$ & & $\begin{array}{c}\text { The mean of } \\
\text { lowest } \\
\text { temperature }\end{array}$ & & $\begin{array}{l}\text { The mean of } \\
\text { rainfall rate }\end{array}$ \\
\hline & $(M)=43.9$ & & $(m)=6$ & & $(P)=138.25$ \\
\hline
\end{tabular}

Table 1. The average of highest and lowest temperatures and rainfall rate at Buryadh station from 1985 to 2008

Source: The General Authority of Meteorology and Environmental Protection 
Germination Assessment for Five Species of Acacia in Jibala, Saudi Arabia

Table 2. The influence of treatments on germination rate for five species of acacia.

\section{Species}

\begin{tabular}{|c|c|c|c|c|c|}
\hline Treatments & A. ehrenbergiana & $\begin{array}{l}\text { A. gerradii var. } \\
\text { najednsis }\end{array}$ & A. nubica & A. raddiana & A. tortilis \\
\hline $\begin{array}{l}\text { mechanical } \\
\text { scarification }\end{array}$ & $91^{\text {bdac }}$ & $100^{\mathrm{a}}$ & $53^{\mathrm{a}}$ & $97^{\mathrm{a}}$ & $93^{\mathrm{a}}$ \\
\hline Acid 5 minutes & $93^{\mathrm{ab}}$ & $13^{\mathrm{fe}}$ & $4^{\mathrm{ced}}$ & $21^{\mathrm{cd}}$ & $83^{\text {bac }}$ \\
\hline Acid 10 minutes & $92^{\mathrm{abc}}$ & $16^{\text {ted }}$ & $4^{\text {ced }}$ & $25^{\mathrm{cd}}$ & $83^{\text {bac }}$ \\
\hline Acid 15 minutes & $97^{\mathrm{a}}$ & $26^{\mathrm{cbd}}$ & $8^{b}$ & $44^{\mathrm{b}}$ & $91^{\mathrm{a}}$ \\
\hline Acid 20minutes & $94^{\mathrm{ab}}$ & $15^{\mathrm{fed}}$ & $4^{\text {ced }}$ & $39^{\mathrm{b}}$ & $92^{\mathrm{a}}$ \\
\hline Acid 25 minutes & $93^{\mathrm{ab}}$ & $23^{\mathrm{ced}}$ & $4^{\mathrm{ced}}$ & $34^{\mathrm{cb}}$ & $89^{\text {ba }}$ \\
\hline Boiling one minute & $81^{\text {bdec }}$ & $34^{\mathrm{cb}}$ & $1^{\mathrm{fe}}$ & $22^{\mathrm{cb}}$ & $70^{c}$ \\
\hline Boiling 3 minutes & $79^{\mathrm{dec}}$ & $38^{\mathrm{b}}$ & $2^{\text {fed }}$ & $20^{\mathrm{d}}$ & $83^{\text {bac }}$ \\
\hline Boiling 5 minutes & $72^{\mathrm{e}}$ & $33^{\mathrm{cb}}$ & $6^{\mathrm{cb}}$ & $21^{\mathrm{cd}}$ & $47^{\mathrm{d}}$ \\
\hline Boiling 7 minutes & $93^{\mathrm{ab}}$ & $31^{\mathrm{cb}}$ & $5^{\mathrm{cbd}}$ & $18^{\mathrm{d}}$ & $34^{\mathrm{d}}$ \\
\hline Soaking 24 hours & $92^{\mathrm{abc}}$ & $10^{f}$ & $7^{\mathrm{cb}}$ & $19^{\mathrm{d}}$ & $72^{\mathrm{bc}}$ \\
\hline Soaking 48 hours & $73^{\mathrm{e}}$ & $11^{\mathrm{fe}}$ & $6^{\mathrm{cb}}$ & $18^{\mathrm{d}}$ & $82^{\text {bac }}$ \\
\hline Soaking 72 hours & $77^{\mathrm{e}}$ & $6^{f}$ & $4^{\text {ced }}$ & $21^{\mathrm{cd}}$ & $82^{\text {bac }}$ \\
\hline control & $78^{\mathrm{de}}$ & $8^{f}$ & $0^{f}$ & $18^{\mathrm{d}}$ & $90^{\mathrm{a}}$ \\
\hline L.S.D & 13.5 & 12.6 & 3.7 & 13.9 & 17.2 \\
\hline
\end{tabular}

L.S.D= Least Significant Difference. Means followed by the same letter in a column are not significantly different at $\mathrm{P}<0.05$.

Table 3. The influence of treatments on coefficient of velocity, mean germination time and germination percentage.

\begin{tabular}{|c|c|c|c|}
\hline Treatments & $\begin{array}{c}\text { Coefficient of velocity of } \\
\text { germination - \% (CV) }\end{array}$ & $\begin{array}{l}\text { Mean germination } \\
\text { time - days (MGT) }\end{array}$ & $\begin{array}{c}\text { Germination percentage - } \% \\
\text { (GP) }\end{array}$ \\
\hline $\begin{array}{l}\text { mechanical } \\
\text { scarification }\end{array}$ & $0.41^{\mathrm{a}}$ & $3.1^{\mathrm{i}}$ & $90.8^{\mathrm{a}}$ \\
\hline Acid 5 minutes & $0.26^{\mathrm{dc}}$ & $4.9^{\mathrm{gef}}$ & $42.9^{\mathrm{cd}}$ \\
\hline Acid 10 minutes & $0.37^{\mathrm{ba}}$ & $3.7^{\text {gif }}$ & $42.9^{\text {cd }}$ \\
\hline Acid 15 minutes & $0.31^{\mathrm{bc}}$ & $4.6^{\text {gefh }}$ & $56.5^{b}$ \\
\hline Acid 20minutes & $0.36^{\mathrm{ba}}$ & $3.92^{\text {gith }}$ & $49^{\mathrm{cb}}$ \\
\hline Acid 25 minutes & $0.37^{\text {ba }}$ & $3.4^{\text {th }}$ & $49.5^{\mathrm{cb}}$ \\
\hline Boiling one minute & $0.21^{\mathrm{de}}$ & $6.7^{\mathrm{bc}}$ & $37.8^{\mathrm{fde}}$ \\
\hline Boiling 3 minutes & $0.21^{\mathrm{de}}$ & $6.4^{\text {bcd }}$ & $41.8^{\text {cde }}$ \\
\hline Boiling 5 minutes & $0.20^{\text {de }}$ & $5.9^{\text {becd }}$ & $32.9^{\text {fe }}$ \\
\hline Boiling 7 minutes & $0.21^{\mathrm{de}}$ & $5.2^{\text {efd }}$ & $30.9^{f}$ \\
\hline Soaking 24 hours & $0.20^{\mathrm{de}}$ & $7.19^{\mathrm{ba}}$ & $38.8^{\mathrm{fde}}$ \\
\hline Soaking 48 hours & $0.24^{\mathrm{de}}$ & $5.47^{\mathrm{bcd}}$ & $35^{\mathrm{fde}}$ \\
\hline Soaking 72 hours & $0.21^{\mathrm{de}}$ & $6.46^{\mathrm{bcd}}$ & $35.2^{\mathrm{fde}}$ \\
\hline control & $0.18^{\mathrm{e}}$ & $8.25^{\mathrm{a}}$ & $34^{\mathrm{fde}}$ \\
\hline L.S.D & 0.069 & 1.4 & 4.8 \\
\hline
\end{tabular}

L.S.D= Least Significant Difference. Means followed by the same letter in a column are not significantly different -at $\mathrm{P}<0.05$. 
Germination Assessment for Five Species of Acacia in Jibala, Saudi Arabia

Table 4. The influence of species on coefficient of velocity, mean germination time and germination percentage.

\begin{tabular}{|c|c|c|c|}
\hline \hline Species & $\begin{array}{c}\text { Coefficient of velocity } \\
\text { of germination-\%(CV) }\end{array}$ & $\begin{array}{c}\text { Mean germination } \\
\text { time - days (MGT) }\end{array}$ & $\begin{array}{c}\text { Germination percentage - } \\
\% \\
(\mathrm{GP})\end{array}$ \\
\hline A. raddiana & $0.29^{\mathrm{b}}$ & $4.18^{\mathrm{c}}$ & $29.9^{\mathrm{c}}$ \\
\hline A. ehrenbergiana & $0.38^{\mathrm{a}}$ & $3.13^{\mathrm{d}}$ & $22.8^{\mathrm{d}}$ \\
\hline A. gerradii & $0.26^{\mathrm{b}}$ & $5.5^{\mathrm{b}}$ & $81.2^{\mathrm{b}}$ \\
\hline A. tortilis & $0.28^{\mathrm{b}}$ & $4.7^{\mathrm{cb}}$ & $5.6^{\mathrm{e}}$ \\
\hline A. nubica & $0.13^{\mathrm{c}}$ & $9.25^{\mathrm{b}}$ & 2.8 \\
\hline L.S.D & 0.04 & & 0.86 \\
\hline
\end{tabular}

L.S.D = Least Significant Difference. Means followed by the same letter in a column are not significantly different at $\mathrm{P}<0.05$ •

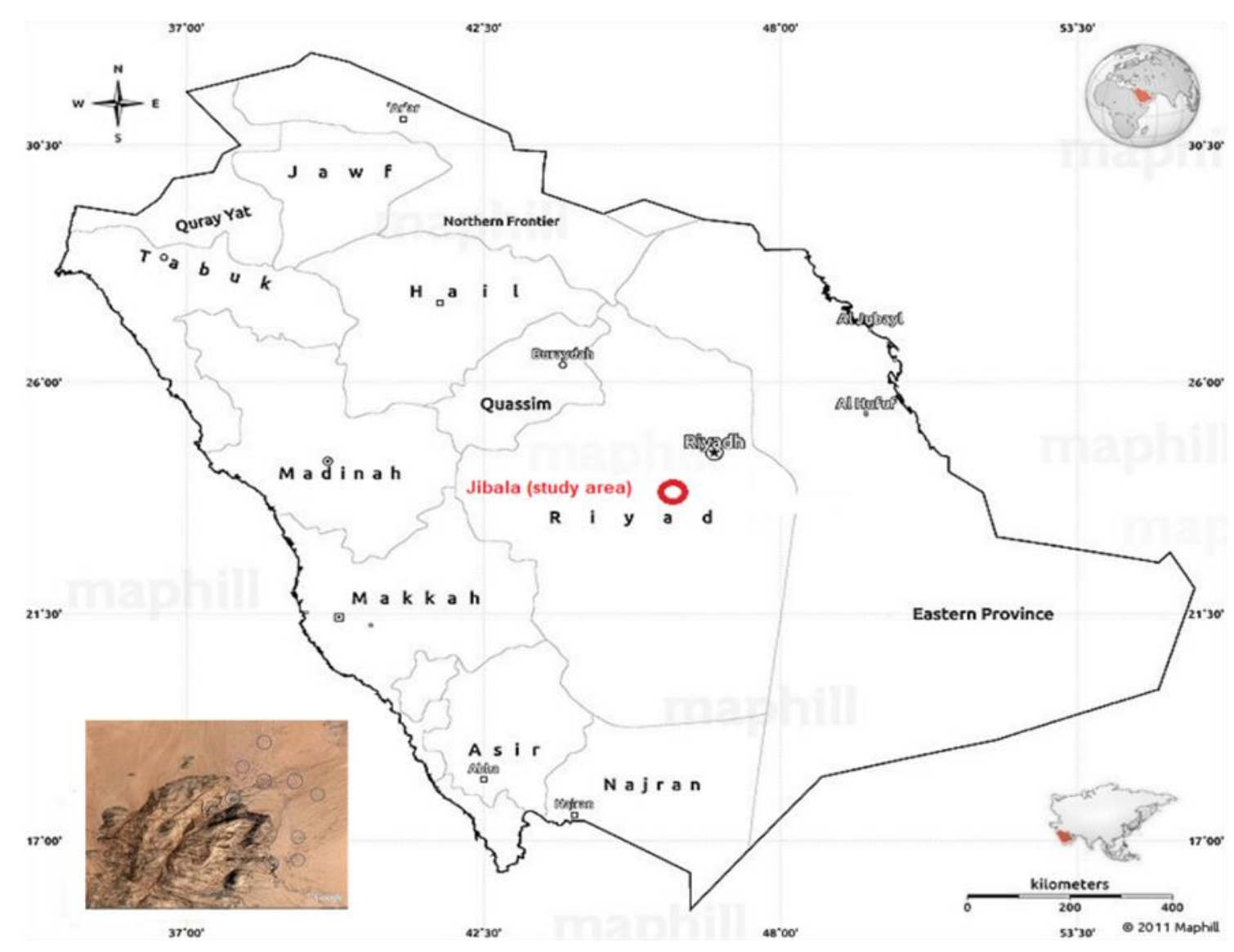

Figure 1. Jibala is located in the Riyadh region of Saudi Arabia (Google Earth). 


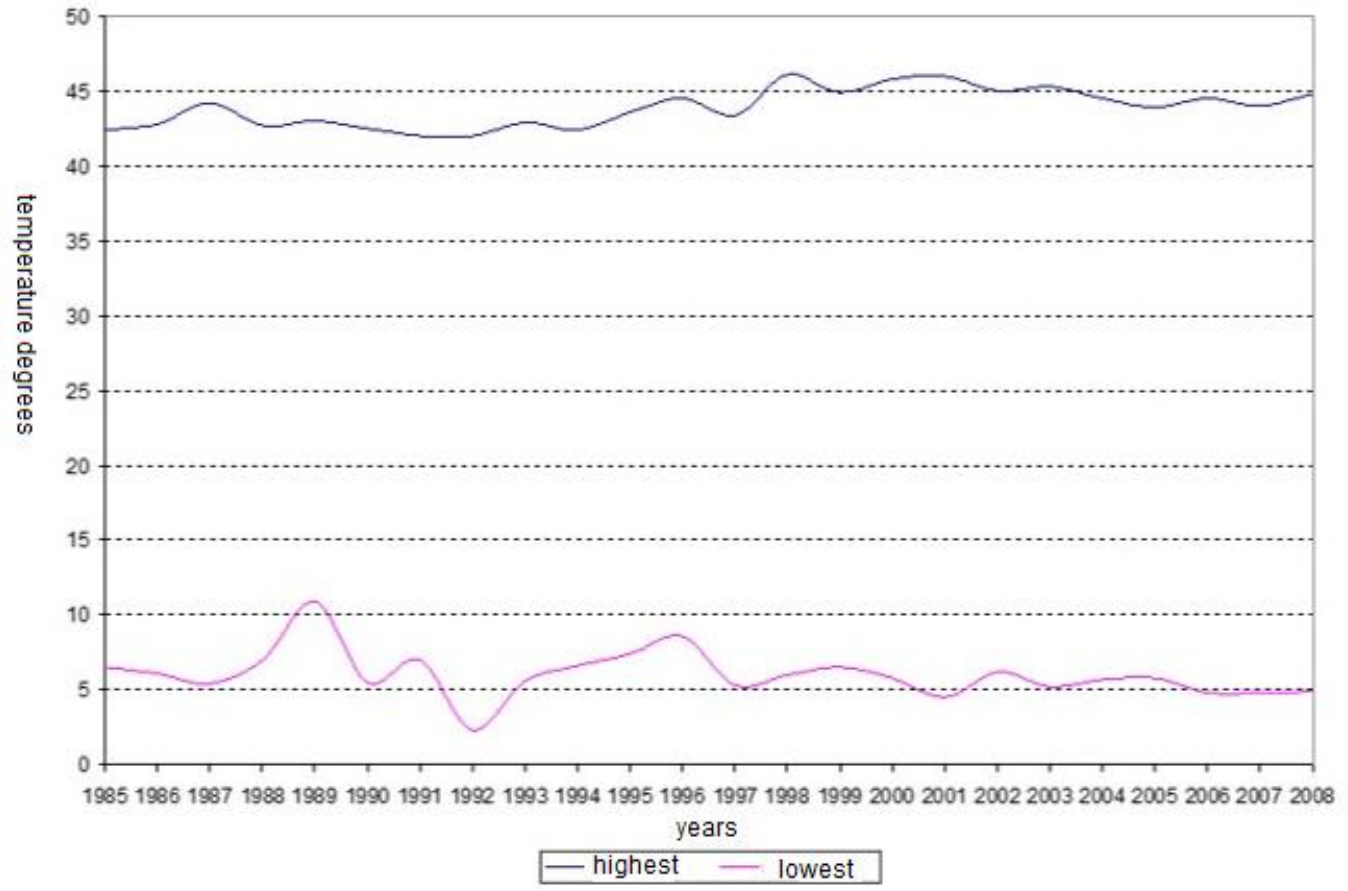

Figure 2. The highest and lowest temperatures from 1985 to 2008 at Buryadh station.

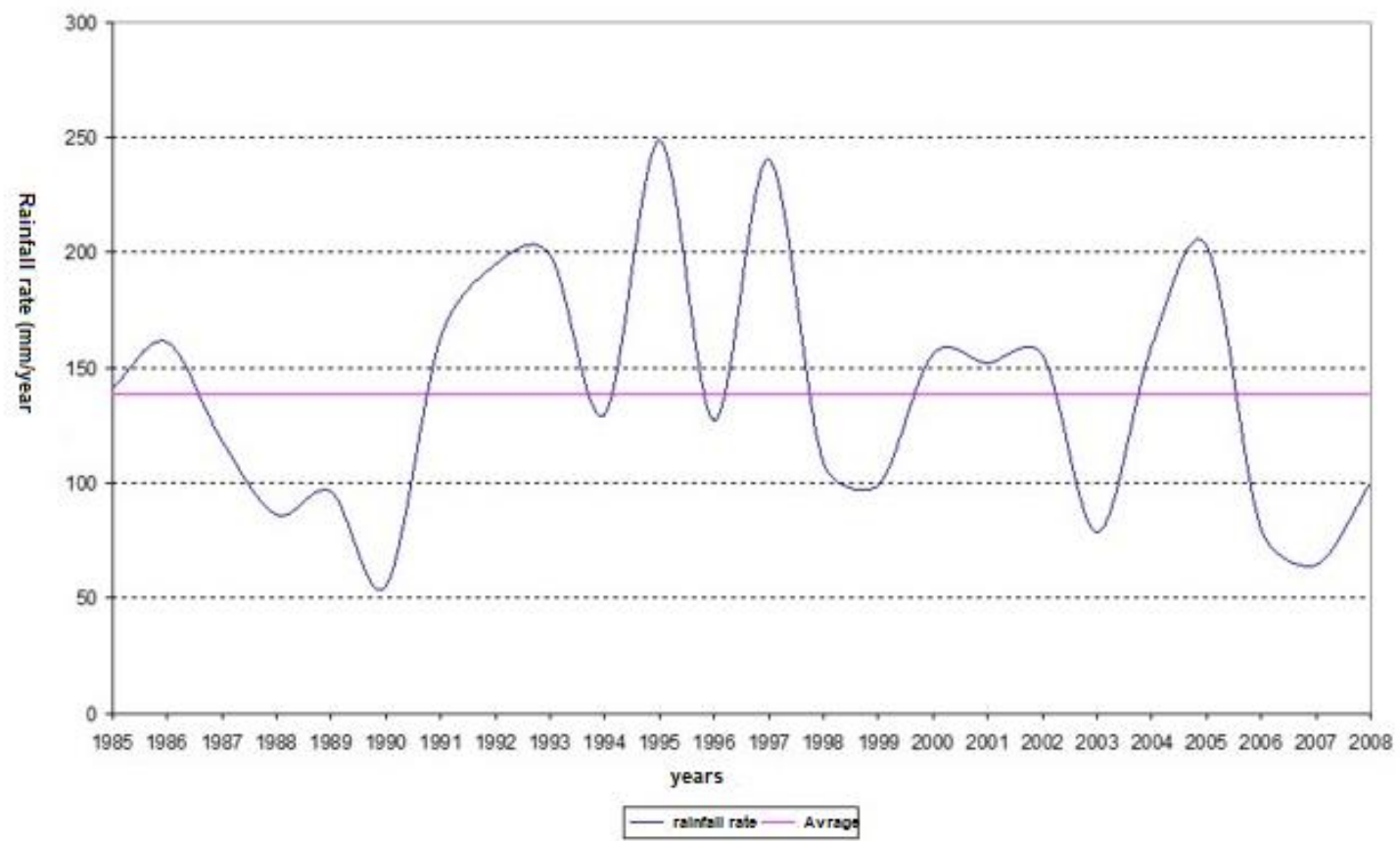

Figure 3. Rainfall rate each year from 1985 to 2008 at Buryadh station. 
Q2

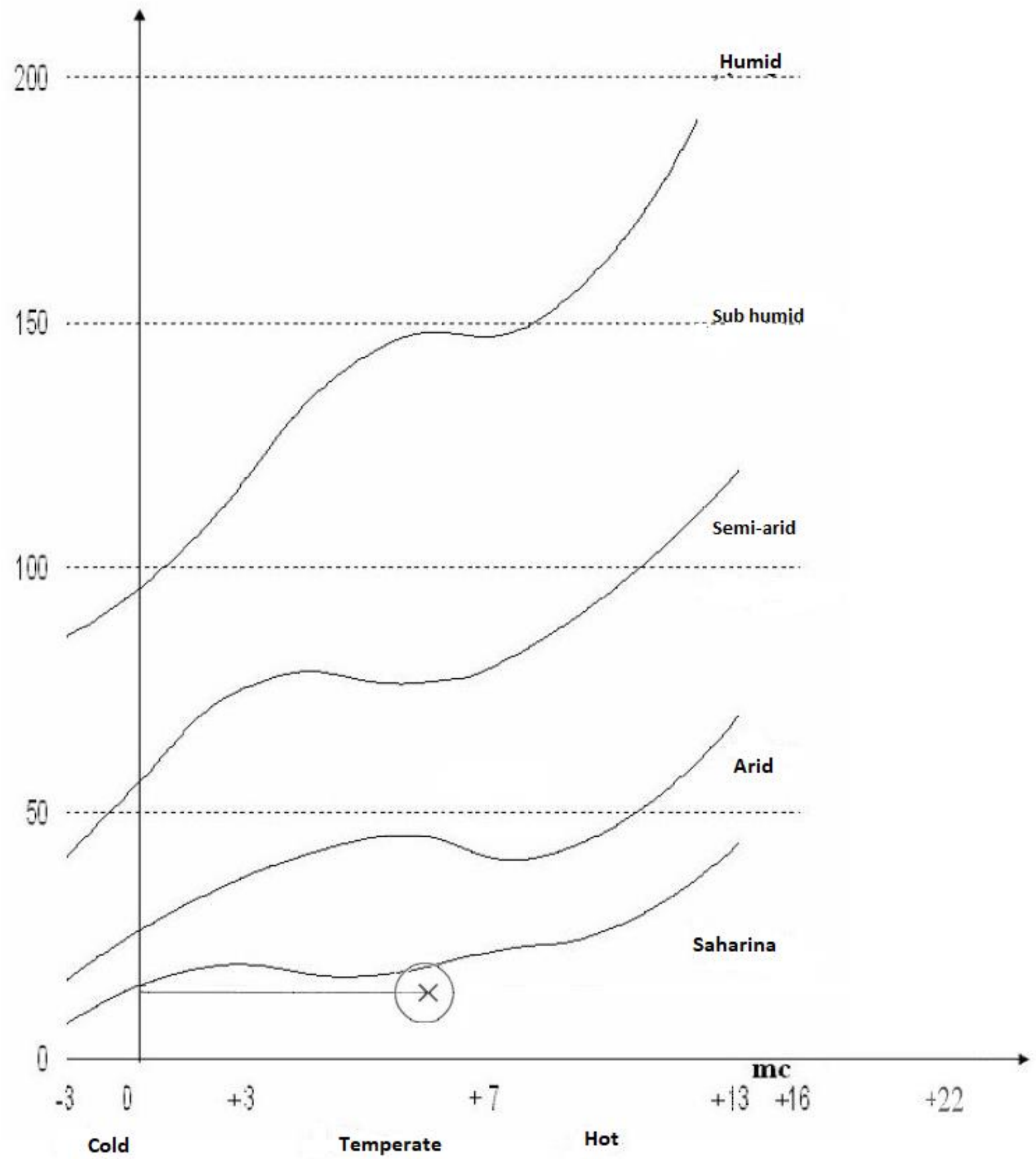

Figure 4. Climate location of Buryadh in (Emberger graph.) 


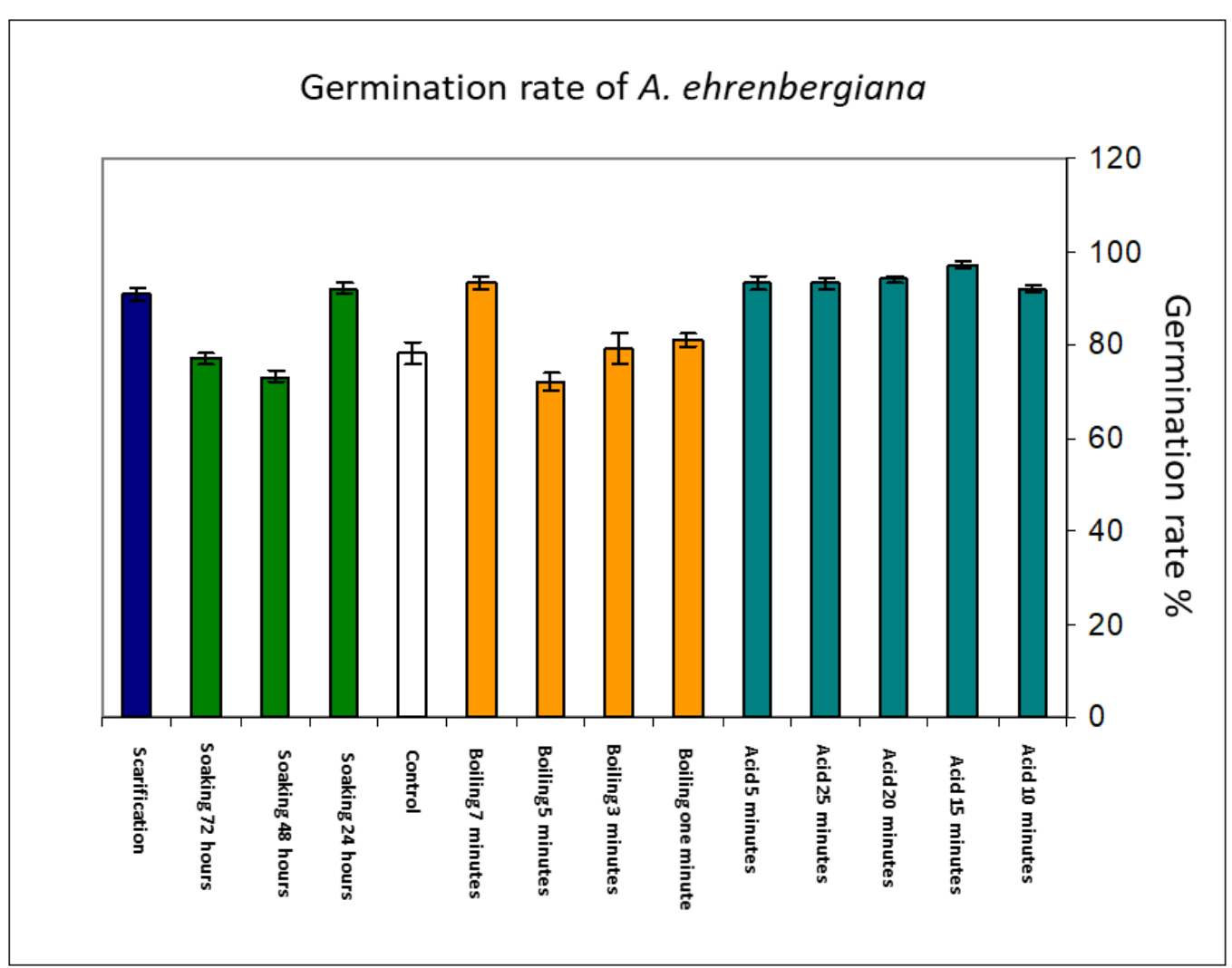

Figure 5. The effect of germination treatments in A. ehrenbergiana.

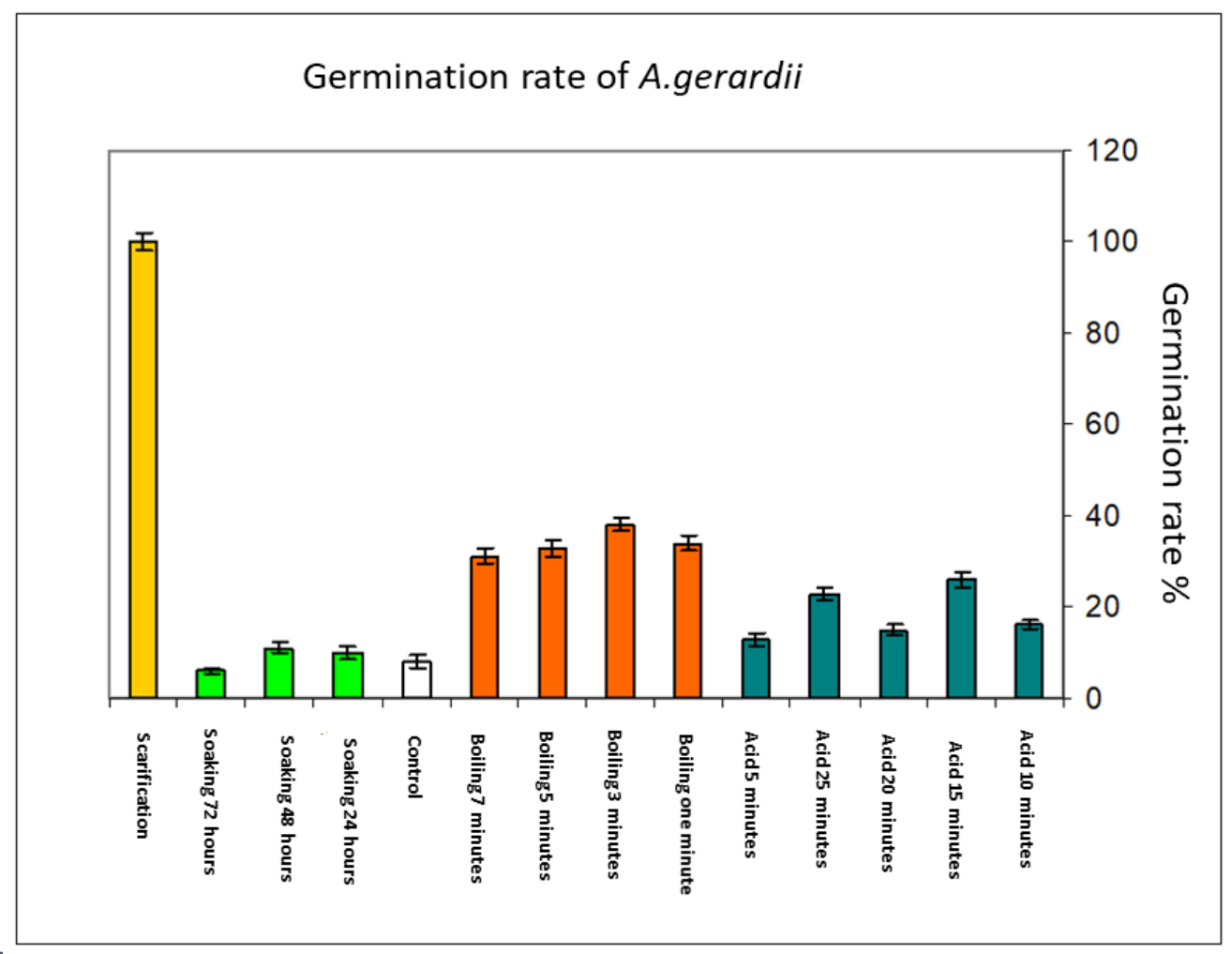

Figure 6. The effect of germination treatments in A. gerardii. 


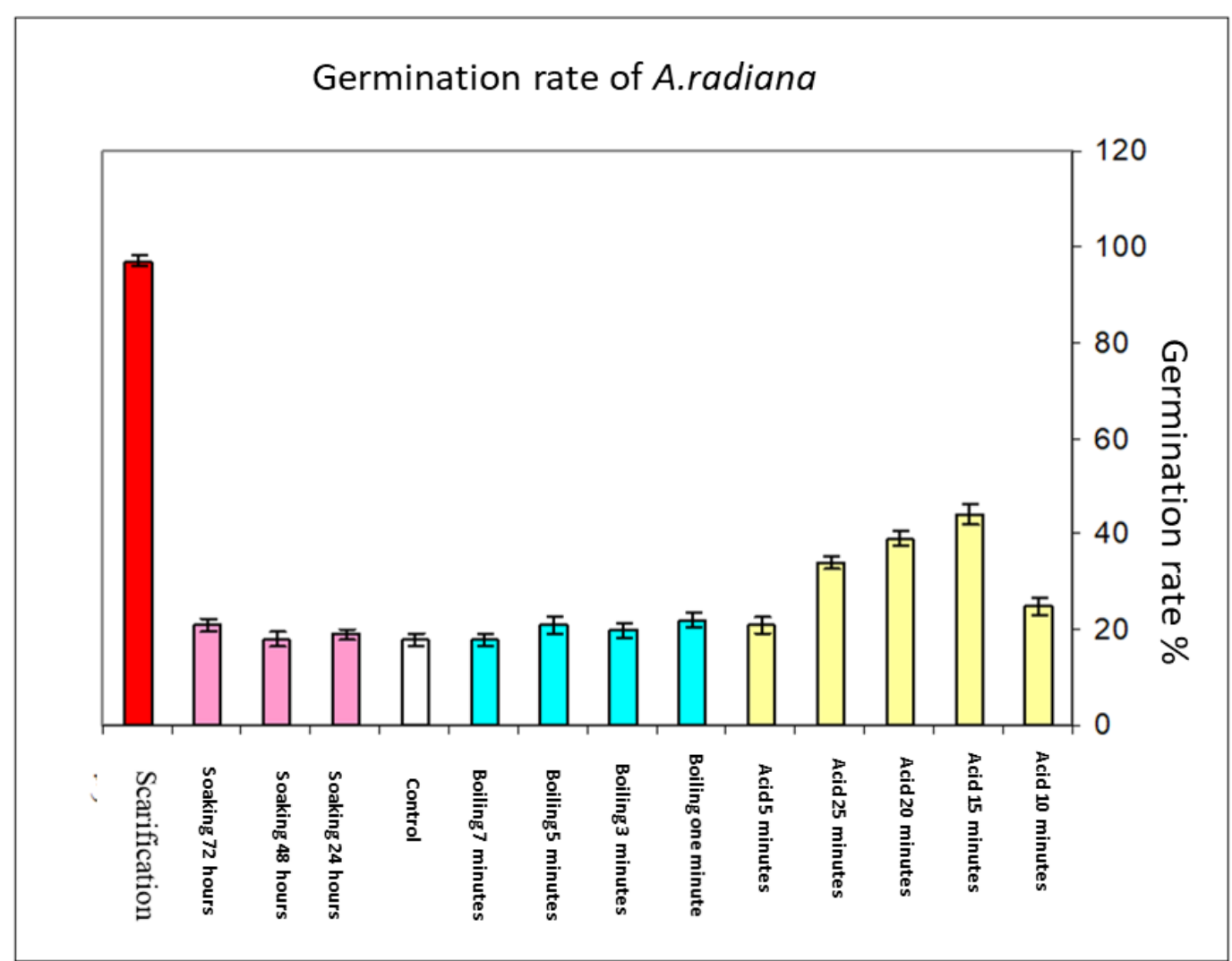

Figure 7. The effect of germination treatments in A. raddiana

\section{Germination rate of A.tortilis}

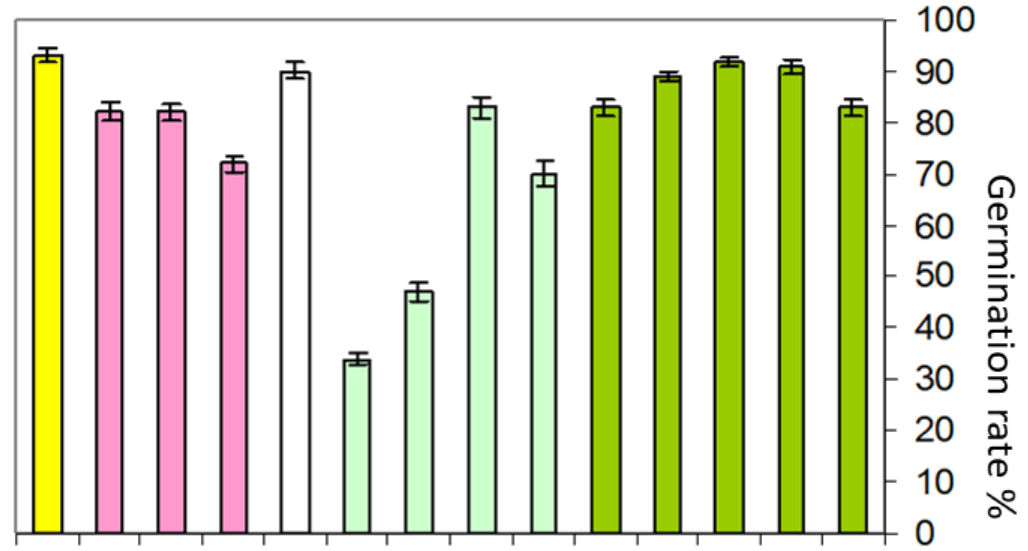

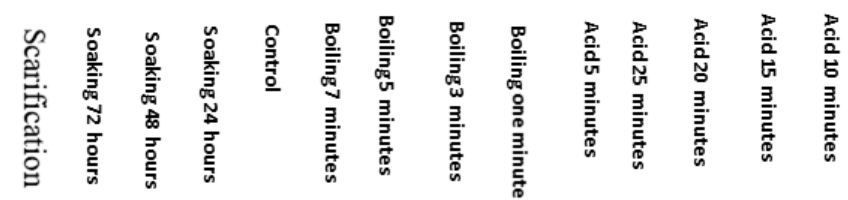

Figure 8. The effect of germination treatments in A. tortilis. 


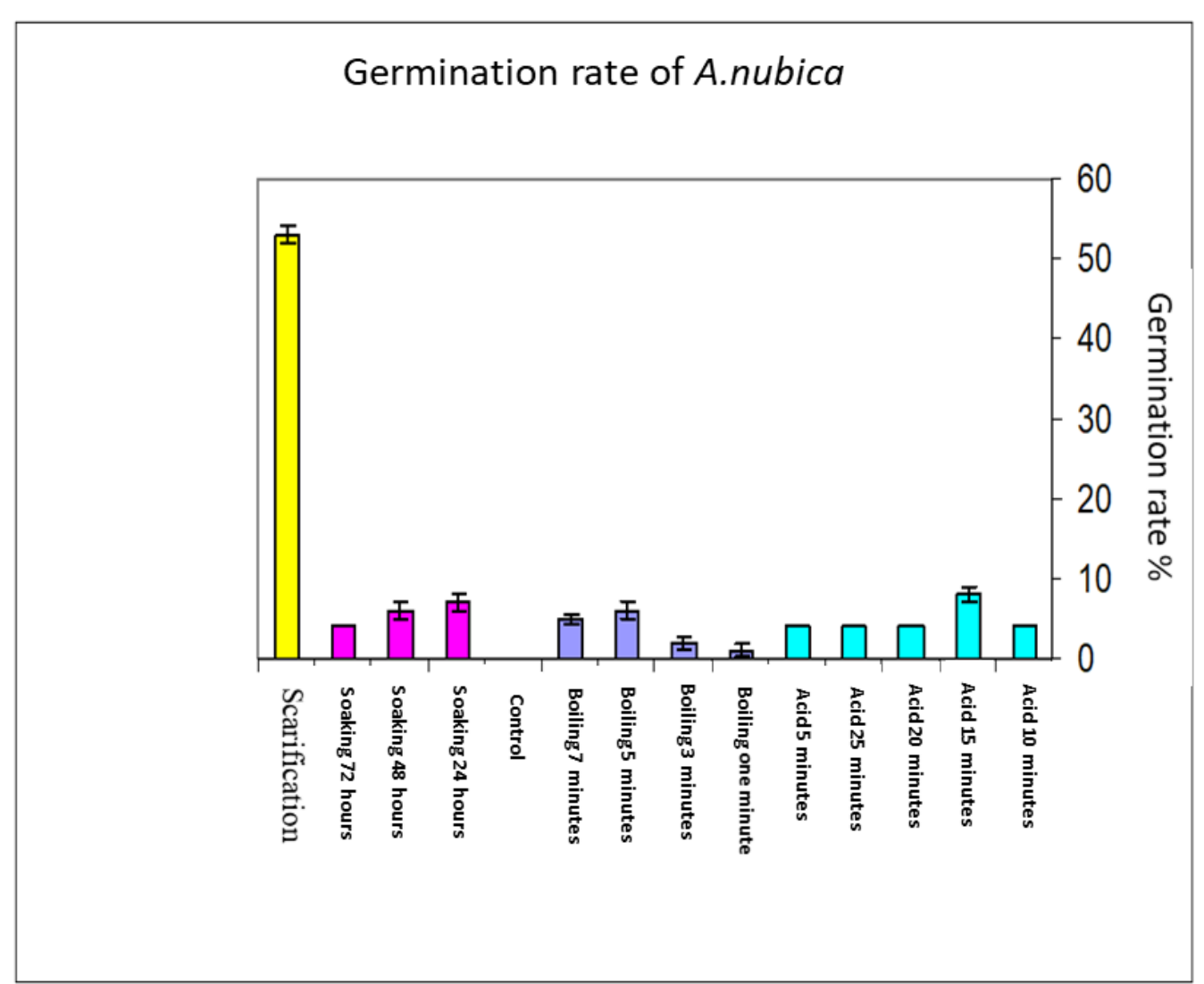

Figure 9. The effect of germination treatments in A. nubica 